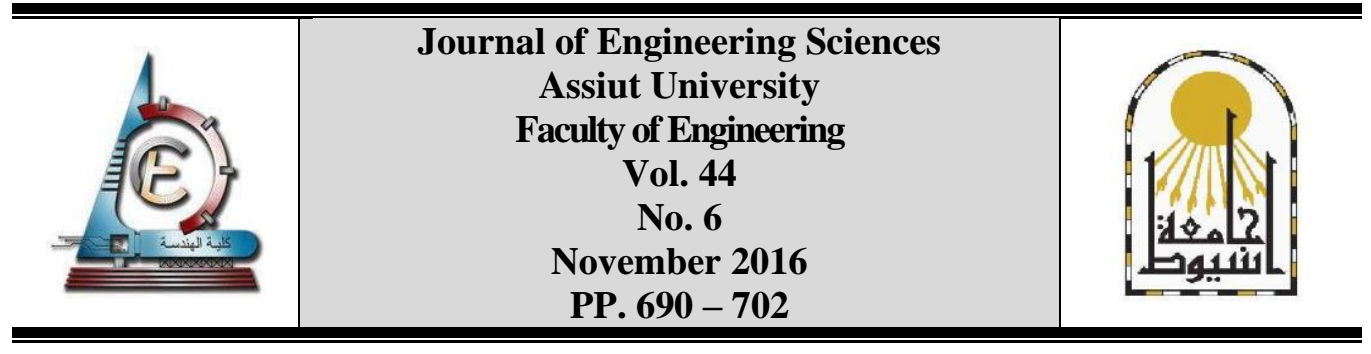

\title{
EFFECT OF ALUM COAGULATION ON IRON REMOVAL IN AERATED GROUNDWATER USING RAPID SAND FILTERS
}

\author{
Mohamed El-Sayed El-dardeer, Ahmed Abdel Halim Mohamed, \\ Ali Abdel Rahman Mohamed, Heba Mohamed Safwat Abdelazim
}

Civil Eng Dept, Faculty of Engineering, Assuit Univ, 71516 Assuit.

Received 21 August 2016; Accepted 19 September 2016

\begin{abstract}
The oxidation process of dissolved iron particles in water changes the iron into red-brown solid particles (particulate), which settle down in the water. Those large particles that settle down in the water can be handled. Nevertheless, iron that does not procedure large enough particles to settle down remains suspended (colloidal iron) and thus leaves the water with red tint. Unfortunately, these particles threat the industry and the municipal of water supplies. This is due to formation of scales as well as blockage of water pipes that lead to economic problems.

Numerous studies have been conducted to study the effect of using oxidation processes followed by the filtration process only for the removal of iron from water. This study introduces a comparison of filtration of aerated raw water though a filter of sand bed with and without Alum as a coagulant prior to filter. A synthetic iron dozes are added to tap water to represent a pre-determined different concentrations of iron as 2 and $3 \mathrm{mg} / \mathrm{L}$ which result in 14 and $32 \mathrm{NTU}$, respectively, after aeration of raw water. The effluent of water was taken at regular time intervals to monitor the progressive rate of removal of these elements for different values of filtration rates 120,180 and $240 \mathrm{~m}^{3} / \mathrm{m}^{2} /$ day. A single layer gravity rapid sand filter was used with sand bed of $70 \mathrm{~cm}$ thickness, effective diameter of $0.7 \mathrm{~mm}$ and uniformity coefficient of 1.57 . During the experiments, the iron concentration and turbidity in the effluent were recorded at all the used filtration rates.

The results show that the low limit of the removal efficiency of iron is $89 \%$ and the high limit is $97 \%$ without coagulation and $78 \%$ to $97 \%$ with coagulation. Also, the higher the concentration of iron and turbidity, in the influent, the higher the efficiency removal of filter for all filtration rates takes place. For all tested parameters of influent iron concentrations and filtration rates, the effluent iron concentrations and effluent turbidities within the allowable limits of Egyptian drinking water specifications $(0.3 \mathrm{mg} / \mathrm{l}$ for iron and $1.0 \mathrm{NTU}$ for turbidity), except for filtration rates exceeds the $180 \mathrm{~m} 3 / \mathrm{m} 2 /$ day the turbidity was above these allowable limits for both cases using coagulant or not. It obvious, also, from experiments that at low concentration of influent iron (below $3 \mathrm{mg} / \mathrm{l}$ ) and filtration rates up to $180 \mathrm{~m} 3 / \mathrm{m} 2 /$ day there is no need to coagulation process.
\end{abstract}

Keywords: Iron removal, filtration, and coagulation.

\footnotetext{
* Corresponding author.

Email address: heba.safwat22@gmail.com
} 


\section{Introduction}

Numerous studies focused on the removal of iron content in groundwater Cheng et al [1]. Generally, groundwater is seen as a reliable source of clean water for consumption. That makes it an ideal source for meeting the demand for potable water in urban areas. The problems associated with the existence of iron in potable water ( more than $0.3 \mathrm{mg} / \mathrm{l}$ ) can be summarized as follows:

1. Iron produces insoluble rusty oxide-red, yellow or brown that stains and streaks on laundry and plumbing fixtures O'Connor [2]; Kothari [3].

2. Iron gives color and typical unpleasant, astringent taste to the water. The taste threshold of iron in water is in the range of $0.04-0.1 \mathrm{mg} / 1$ Montgomery [4]; WHO [5]. Moreover, turbidity and color may appear in piped systems at iron levels above $0.05-0.1 \mathrm{mg} / 1$ WHO [5].

3. The presence of iron is undesirable in water supplies, since it provides nuisance for domestic and industrial uses.

Iron presence in groundwater is one of the following three forms: 1) dissolved, 2) particulates, and 3) colloidal. Numerous regulatory agencies have put standards and/ or guidelines to control iron concentrations in water supplies in order to avoid the difficulties mentioned above. That control of iron concentrations in water supplies is a significant issue. For an ideal quality water for public use, the American Water Works Association (AWWA) suggested limits of $0.05 \mathrm{mg} / 1$ for iron Bean [6].

\section{Iron removal methods}

The process of aeration and filtration are adapted for removing iron and manganese from the groundwater Aral [7]. The filtration process is varied according to the filtration media used. Sand, or silica, or quarts can be used as a filtration media Robinson and Lloyd [8]; Kaleta et al [9]; Fadel, and Fadel [10]. Moreover, manganese oxide-coated or natural manganese sand can be used as filtration media Piispanen and Sallanko [11]; Heng et al.[12]. In order to enhance the removal of pollutants presence in the groundwater for the purpose of drinking water, the micro-filtration process has been carried out Wen-Hsiang et al. [13]. Recently, biological methods are used by many researchers for the treatment of groundwater Tang et al. [14], or combining physicochemical and biological methods Olańczuk-Neyman, and Bray [15]. Therefore, removing iron from groundwater can be accomplished in several ways as follows:

1. Oxidation-precipitation-filtration process,

2. Ion exchange or zeolite softening process,

3. Stabilization process or sequestering using silicates or polyphosphates,

4. Lime softening or limestone bed filtration process,

5. Manganese greensand process, and/ or

6. Membrane processes.

\section{Using coagulation and flocculation in iron removal process}

In general, the type of treatment used, basically, depends on the quality of the raw water. Iron existed in raw water can be oxidized by aeration then changed into non-soluble state (suspend solids) causing the water turbidity. The removal process of these turbidities depends on the concentration of iron in the raw water. Egyptian code of practice indicates that if the iron 
concentration is above $1.5 \mathrm{mg} / \mathrm{l}$, coagulation and flocculation step must be used prior to the filtration process. Therefore, the removal process of iron consists of the following steps:

1. Oxidation of $\mathrm{Fe}^{2+}$ to $\mathrm{Fe}^{3+}$ by aeration or by a chemical oxidant,

2. Hydrolysis of $\mathrm{Fe}^{3+}$ to iron hydroxides,

3. Flocculation/ agglomeration of the hydroxide particles, and

4. Removal of flocs in rapid sand filters.

This removal process of iron is $\mathrm{pH}$-dependent and dominant at $\mathrm{pH}$ values above 8.5. Under this situation, the oxidation is happened quickly and flocs are formed prior to entering the filter bed. The rapid development of head loss (due to clogging of filters) coupled with rapid deterioration of filtrate quality are often responsible for short filter runs and frequent backwashing cycles of iron removal plant. In this study, alum is used as a coagulant. The experiments are carried out with and without alum at different rates of filtration and different iron influent concentrations. A comparison is made between the two cases to show the effect of adding alum on the removal efficiency of iron at different influent concentrations.

\section{Processes using rapid gravity filtration}

In case that the anoxic groundwater is aerated, (or treated with chemical oxidants) the produced iron floc has a positive surface charge. This positive surface charge makes the flocs repel each other and therefore makes them difficult to coagulate, settle and filter. In order to obtain an optimum treatment, physical-chemical treatment rates can be as low as 1 to $2 \mathrm{~m} / \mathrm{h}$ for settlement and 4 to $5 \mathrm{~m} / \mathrm{h}$ for filtration. Moreover, these rates can be enhanced by the existence of naturally occurring negatively charged particles which neutralize the repulsive forces. With a limited filter capacity and at iron concentrations above $2 \mathrm{mg} / \mathrm{l}$ filter, backwash frequencies can become unacceptably short besides manganese removal may be compromised. In these cases, a settlement stage or a microbiological filter should be used to reduce the load on the filters before the rapid gravity filters. The choice of a treatment method (Table (1)) depends, significantly, on the water quality that for many groundwater sources can be categorized as:

- Iron only,

- Iron and manganese, and

- Iron, manganese and ammonia (and hydrogen sulphide).

\subsection{Iron only}

The aeration and rapid gravity filtration can be used to remove iron at concentrations below $2 \mathrm{mg} / \mathrm{l}$. For the ideal performance, a filter bed depth of $1 \mathrm{~m}$ should be used (consisting of $90 \%$ of $0.65 \mathrm{~mm}$ sand, and $10 \%$ of a suitable grain size of granular manganese dioxide). The granular manganese dioxide is sized to stay mixed with the sand after backwashing that may vary with the source of the manganese dioxide. Filtration rates are, typically, in the range of 4 to $6 \mathrm{~m} / \mathrm{h}$. Other filter media such as greensand and treated sands can be used to obtain good performance. In the case of the iron concentration is above $2 \mathrm{mg} / \mathrm{l}$, settlement of $2 \mathrm{~m} / \mathrm{h}$ or microbiological filter stage of $50 \mathrm{~m} / \mathrm{h}$ should be used prior to the filters. Moreover, if organic complication of the iron is an issue, then, chemical oxidants should be used after aeration Postawa et al. [16]. 
Table 1.

The choice of treatment methods

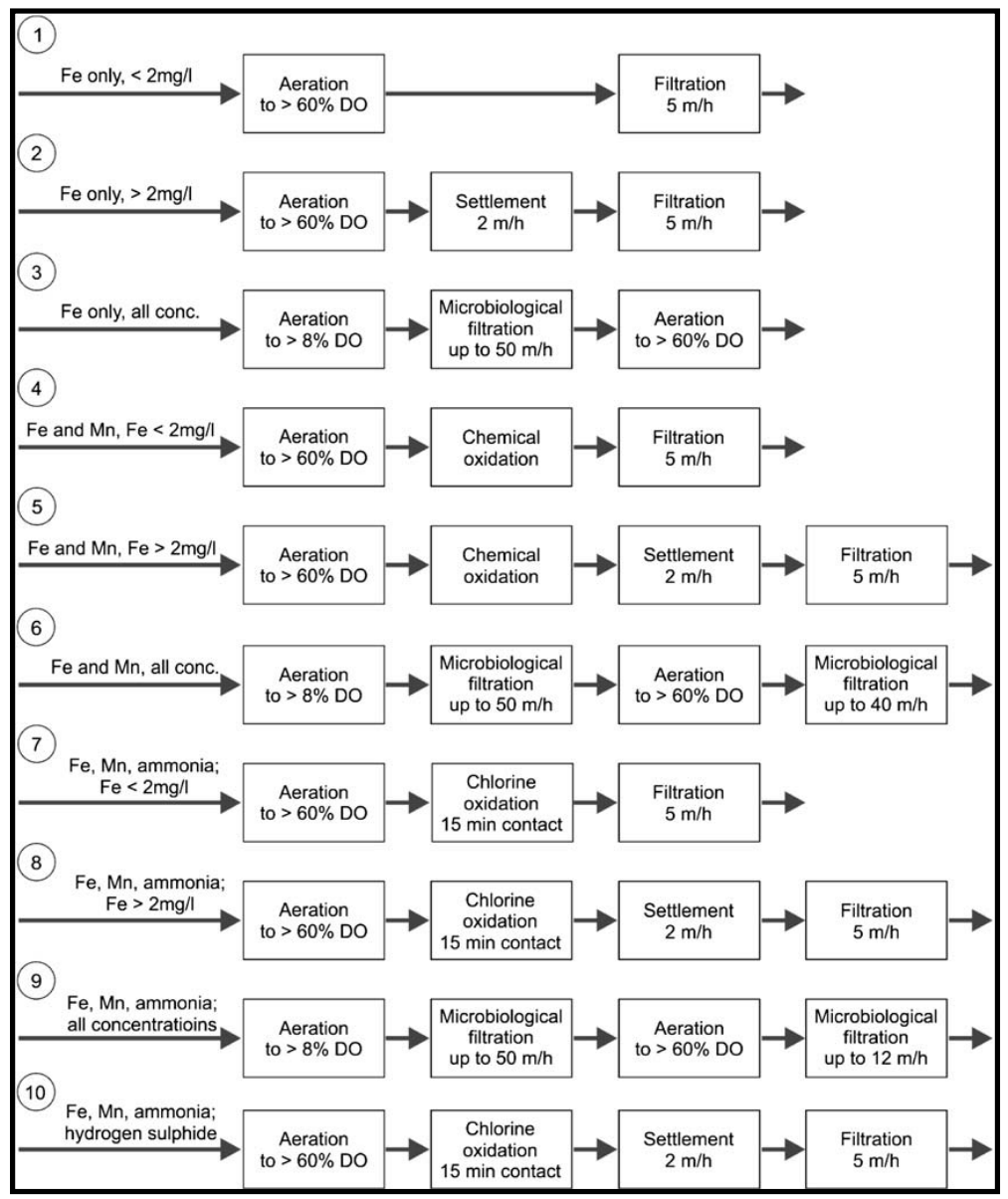

\subsection{Methodology}

\subsubsection{Experiment design}

In this study, the types of raw water samples that have been used are synthetic water samples prepared at the laboratory for testing the suitability and the success of proposed pilot plant for iron and turbidity removal. These synthetic stock water samples were prepared by addition of a Ferrous Ammonium Sulfate $\left(\mathrm{Fe}\left(\mathrm{NH}_{4}\right)_{2} \mathrm{SO}_{4} \cdot 2 \mathrm{H}_{2} \mathrm{O}\right)$ to the distilled water. The synthetic water samples were mixed with tap water to get different influent iron concentrations of $(2 \mathrm{mg} / \mathrm{l}$, and $3 \mathrm{mg} / \mathrm{l})$. The aeration of turbid water was done by using an electrical motor for 30 minutes before beginning of the experimental runs. The treatment process is demonstrated in Fig. (1). In Figure (1), the aerated water is pumped to a constant head tank to get constant filtration rates on the filter. The water flows downward in a sand of an effective size of $0.7 \mathrm{~mm}$ and depth of $70 \mathrm{~cm}$. The filtration rates were calculated and changed as $\left(120,180\right.$, and $240 \mathrm{~m}^{3} / \mathrm{m}^{2} /$ day $)$. 


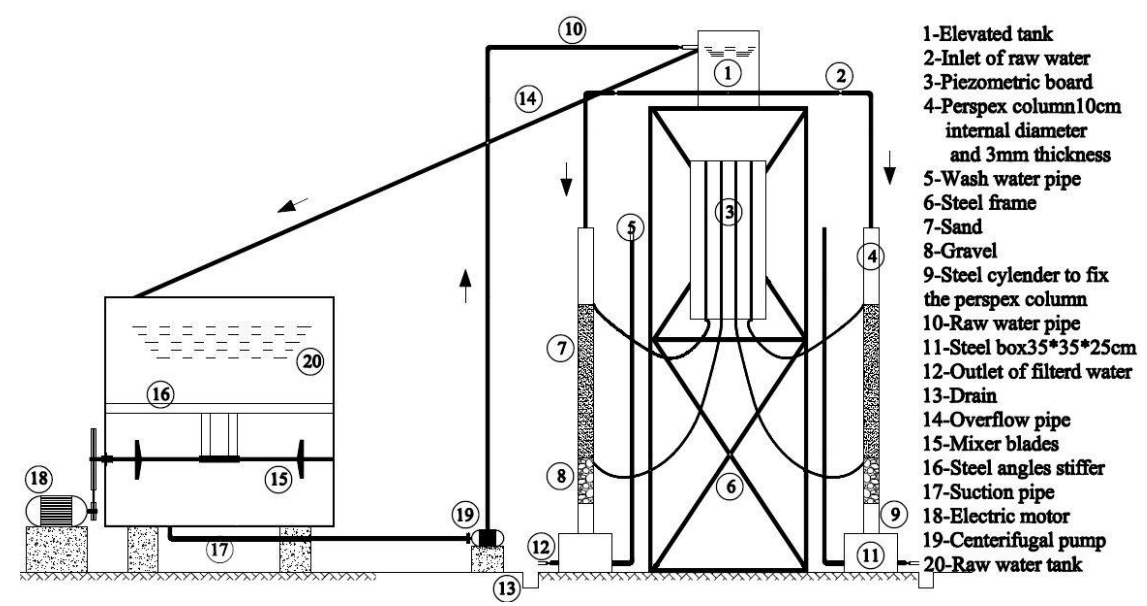

Fig. 1. Representation diagram of the filtration system

The same experiments were carried out by adding alum as a coagulant in raw mixing tank where the doze of alum was determined by jar test apparatus and changed two times $(15 \mathrm{mg} / \mathrm{l}$ and $20 \mathrm{mg} / \mathrm{l})$ for iron concentration $(2 \mathrm{mg} / \mathrm{l}$ and $3 \mathrm{mg} / \mathrm{l})$ receptivity as shown in the following two Tables:

Table 2.

The results of Jar test apparatus at doze of alum $(15 \mathrm{mg} / \mathrm{l})$

$$
\mathrm{Fe}=2 \mathrm{mg} / 1 \quad \mathrm{PH}=8.70 \quad \mathrm{C}_{\mathrm{i}}=14 \mathrm{NTU} \quad \mathrm{T}=30.70^{\circ} \mathrm{C}
$$

\begin{tabular}{|c|c|c|c|c|}
\hline No & DOSE & Residual & PH & $\mathrm{T}^{\mathrm{o}} \mathrm{C}$ \\
\hline 1 & $10 \mathrm{mg} / 1$ & 1.50 & 7.70 & 30.20 \\
\hline 2 & $15 \mathrm{mg} / 1$ & 0.87 & 6.58 & 30.30 \\
\hline 3 & $20 \mathrm{mg} / 1$ & 1.04 & 6.35 & 30.20 \\
\hline 4 & $25 \mathrm{mg} / 1$ & 1.52 & 6.09 & 30.10 \\
\hline 5 & $30 \mathrm{mg} / 1$ & 1.92 & 5.68 & 30.10 \\
\hline 6 & $35 \mathrm{mg} / 1$ & 1.90 & 5.15 & 30.10 \\
\hline
\end{tabular}

Table 3.

The results of Jar test apparatus at doze of alum $(20 \mathrm{mg} / \mathrm{l})$

$$
\mathrm{Fe}=3 \mathrm{mg} / 1 \quad \mathrm{PH}=10.50 \quad \mathrm{C}_{\mathrm{i}}=32 \mathrm{NTU} \quad \mathrm{T}=30.70^{\circ} \mathrm{C}
$$

\begin{tabular}{|c|c|c|c|c|}
\hline No & DOSE & Residual & PH & $\mathrm{T}^{\circ} \mathrm{C}$ \\
\hline 1 & $10 \mathrm{mg} / 1$ & 1.9 & 7.55 & 33.00 \\
\hline 2 & $15 \mathrm{mg} / 1$ & 1.85 & 7.15 & 32.90 \\
\hline 3 & $20 \mathrm{mg} / 1$ & 1.63 & 6.90 & 32.80 \\
\hline 4 & $25 \mathrm{mg} / 1$ & 1.81 & 6.60 & 32.60 \\
\hline 5 & $30 \mathrm{mg} / 1$ & 2.3 & 6.50 & 32.70 \\
\hline 6 & $35 \mathrm{mg} / 1$ & 2.2 & 5.30 & 32.80 \\
\hline
\end{tabular}

The iron was measured by HI83200 multipara meter bench photometer by phenantroline method, for natural and treated waters. Also turbidity was measured by TB 300 IR turbid meter and the jar test is used to determine the optimum doze of coagulant.

\subsection{Results and discussions}

This study explains and discusses the process of turbidity removal resulted from the aerated raw water contains high concentration of iron using the down flow filter with direct 
Heba Mohamed Safwat Abdelazim, Effect of alum coagulation on iron removal in aerated .........

filtration. The study deals with iron removal using the alum as a coagulant. The depth of sand and the effective size are kept constant through all the experimental runs.

The main parameters affecting the effluent turbidity $\left(\mathrm{C}_{\mathrm{e}}\right)$ and the effluent iron concentration $\left(\mathrm{Fe}_{\mathrm{e}}\right)$ from the down flow filter are:

1. The filtration rate $(R) \mathrm{m}^{3} / \mathrm{m}^{2} /$ day,

2. The influent concentration $\left(\mathrm{Fe}_{\text {in }}\right) \mathrm{mg} / \mathrm{L}$,

3. The influent turbidity $\left(\mathrm{C}_{\mathrm{i}}\right)$ measured in NTU, and

4. Type of coagulant, dose and $\mathrm{pH}$.

In this study, the Alum was used as coagulant and Jar test was used to determine the dose of coagulant. Also, the time and type of aeration used were kept constant throughout all the runs.

The values of different parameters are selected to cover the range of most values dominated in the filed of such works. The analysis and discussions of iron removal concern the both cases of using coagulation and with it for the following variables:

1. The effect of filtration rate $(\mathrm{R})$ on the effluent turbidity $\left(\mathrm{C}_{\mathrm{e}}\right)$, the effluent concentration of iron $\left(\mathrm{Fe}_{\mathrm{e}}\right)$, turbidity removal efficiency $\left(\mathrm{E}_{\mathrm{c}}\right)$ and iron removal efficiency $\left(\mathrm{E}_{\mathrm{i}}\right)$.

2. The effect of influent turbidity $\left(\mathrm{C}_{\mathrm{i}}\right)$ on the effluent turbidity $\left(\mathrm{C}_{\mathrm{e}}\right)$, the effluent concentration of iron $\left(\mathrm{Fe}_{\mathrm{e}}\right)$, turbidity removal efficiency $\left(\mathrm{E}_{\mathrm{c}}\right)$ and iron removal efficiency $\left(\mathrm{E}_{\mathrm{j}}\right)$.

3. The effect of influent concentration of iron $\left(\mathrm{Fe}_{\mathrm{in}}\right)$ on the effluent turbidity $\left(\mathrm{C}_{\mathrm{e}}\right)$, the effluent concentration of iron $\left(\mathrm{Fe}_{\mathrm{e}}\right)$, turbidity removal efficiency $\left(\mathrm{E}_{\mathrm{c}}\right)$ and iron removal efficiency $\left(\mathrm{E}_{\mathrm{i}}\right)$.

\section{Case (1): Study of iron removal without coagulation}

\subsection{Turbidity removal}

Figures (2) and (3) show the relation between effluent turbidity and time for different filtration rates at influent turbidity of 14 and 32 NTU. It is shown that for different values of filtration rates, the effluent turbidity decreases with increase of time until a certain limit (depends on the filtration rate). It starts to increase again. It is shown; also, that at high values of filtration rates $\left(240 \mathrm{~m}^{3} / \mathrm{m}^{2} /\right.$ day) and influent turbidity (32 NTU) the effluent turbidity is higher than 1 NTU.

The results can be explained by that at high values of influent turbidity, the suspended matter closes the pores of sand bed rapidly and under the pressure of the water the suspended material leaves the filter.

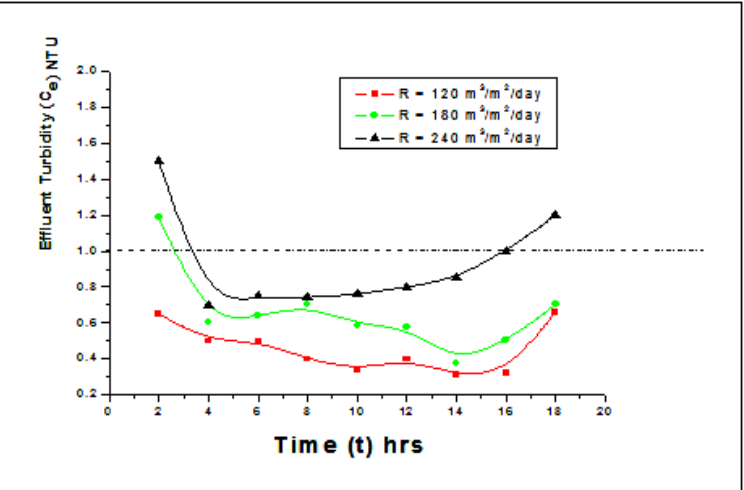

Fig. 2. The effluent turbidity versus time at different filtration rates.

$$
\mathrm{C}_{\mathrm{i}}=14 \mathrm{NTU}, \mathrm{Fe}=2 \mathrm{mg} / \mathrm{l}
$$




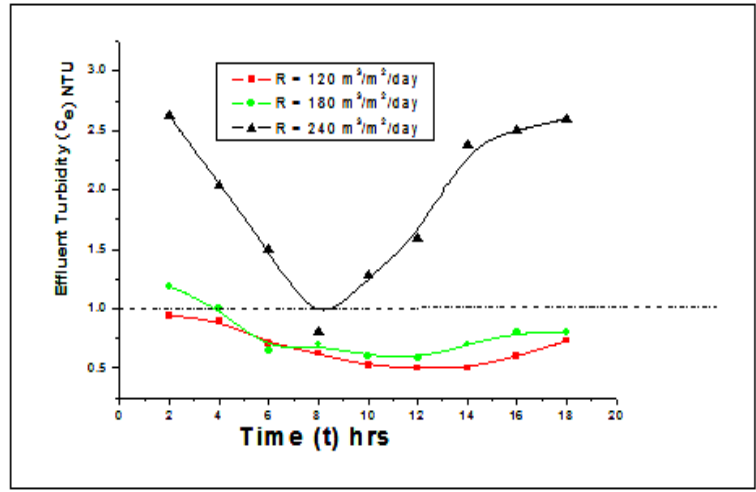

Fig. 3. The effluent turbidity versus time at different filtration rates.

$$
\mathrm{C}_{\mathrm{i}}=32 \mathrm{NTU}, \quad \mathrm{Fe}=3 \mathrm{mg} / \mathrm{l}
$$

\subsection{Iron removal}

The relationship between effluent iron $\left(\mathrm{Fe}_{\mathrm{e}}\right) \mathrm{mg} / \mathrm{L}$ and time at different filtration rates for iron influent of $2 \mathrm{mg} / \mathrm{L}$ and $3 \mathrm{mg} / \mathrm{L}$ are plotted in Figures (4) and (5). From the shown figures, it is clear to notice that the values of effluent iron are below $0.3 \mathrm{mg} / \mathrm{L}$ (meet the allowable values according to Egyptian standards of specifications), for all values of filtration rates.

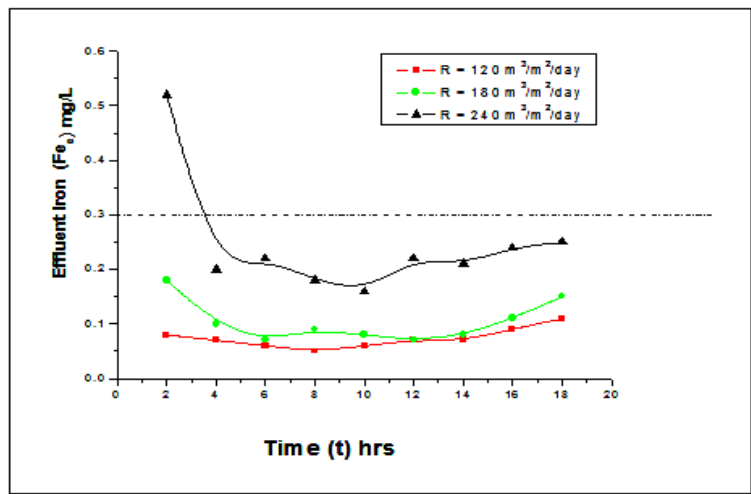

Fig. 4. The effluent iron versus time at different filtration rates.

$$
\mathrm{C}_{\mathrm{i}}=14 \mathrm{NTU}, \mathrm{Fe}=2 \mathrm{~m} / \mathrm{l} \text {. }
$$

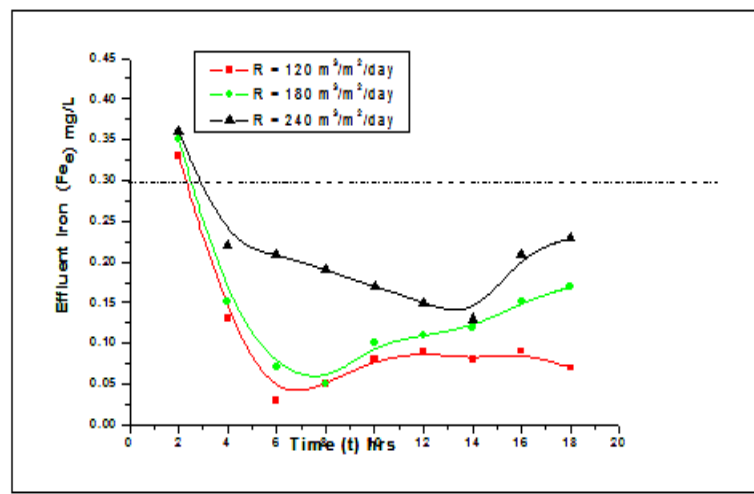

Fig. 5. The effluent iron versus time at different filtration rates.

$$
\mathrm{C}_{\mathrm{i}}=32 \mathrm{NTU}, \mathrm{Fe}=3 \mathrm{~m} / \mathrm{l} \text {. }
$$




\section{Case 2: Iron removal using coagulation}

\subsection{Turbidity removal}

The Jar Test was used to find the optimum dose of alum that can be added to raw water. The alum does were 15 and $20 \mathrm{mg} / \mathrm{L}$ for the corresponding turbidities in the raw water of 14 and $32 \mathrm{mg} / \mathrm{L}$ respectively.

Figures (6) and (7) show the relationship between effluent turbidities and time for different filtration rates after adding alum as coagulant to improve the turbidity removal. It was noticed that effluent turbidity $C_{e}$ decreases in the same run up to 4 hours then the values of $C_{e}$ starts to increase again but still its values less than $1 \mathrm{NTU}$ for all values of filtration rates. Figure (7) shows that the values of effluent turbidity increases after 2 hours with time which result in decrease of the filtration run due to the high turbid water in the influent (32 NTU)

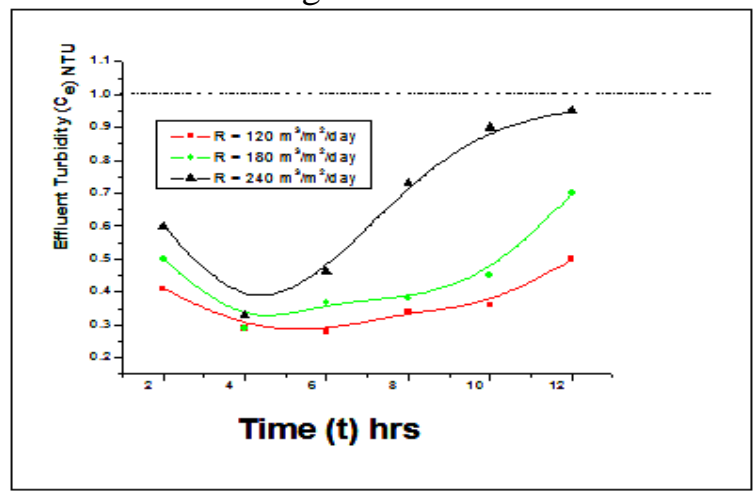

Fig. 6. The effluent turbidity versus time at different filtration rates $\mathrm{C}_{\mathrm{i}}=14 \mathrm{NTU}, \mathrm{Fe}=2 \mathrm{mg} / \mathrm{l}$. Alum dose $15 \mathrm{mg} / \mathrm{L}$.

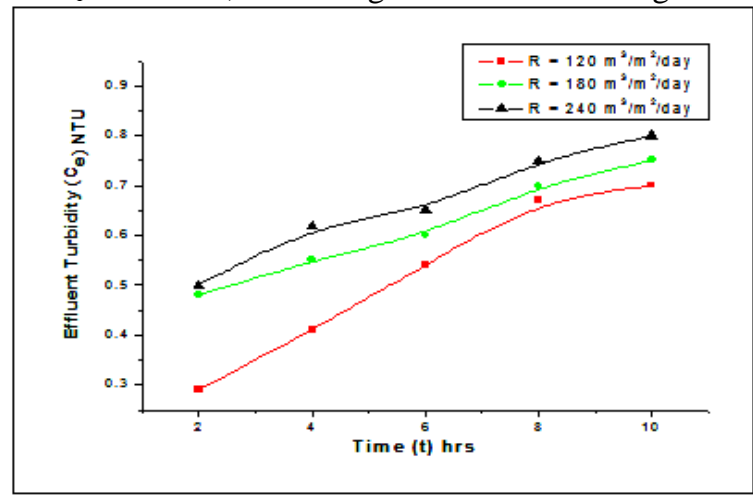

Fig. 7. The effluent turbidity versus time at different filtration rates. $\mathrm{C}_{\mathrm{i}}=32 \mathrm{NTU}, \mathrm{Fe}=3 \mathrm{mg} / \mathrm{l}$. Alum dose $20 \mathrm{mg} / \mathrm{L}$.

\subsection{Removal of iron using alum coagulation}

In this study, the raw water iron concentrations are changed two times. The aeration of raw water changes the state of iron from ferrous to ferric state. The ferric hydroxide gives a brownish color and turbid water. The measure of iron concentration, in the samples, represents the total iron (soluble and insoluble).

Figures (8) and (9) illustrate the relationships between the effluent concentration of iron and time for different influent concentrations of iron and filtration rates. From these figures, it is 
clearly noticed that the effluent concentration of iron decreases for all values of filtration rates and influent concentrations of iron. The results show that for all values of filtration rates and the tested iron concentrations of raw water, the effluent iron concentration does not exceed the allowable limit of $0.3 \mathrm{mg} / \mathrm{L}$ according the specification of drinking water in Egypt.

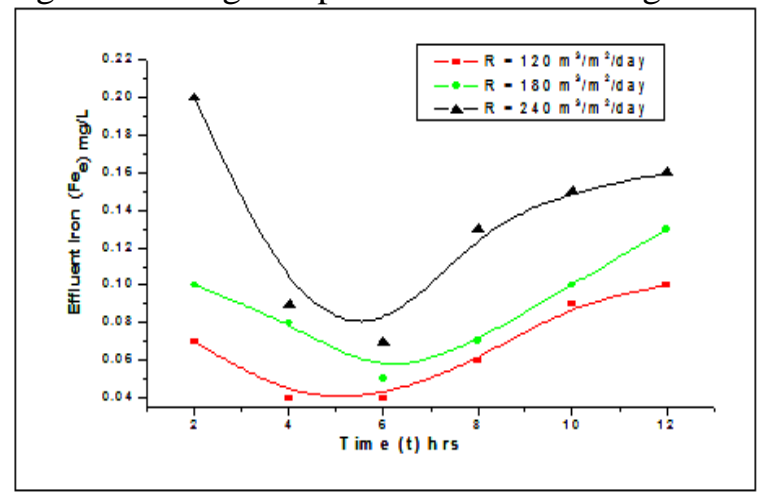

Fig. 8. The effluent iron versus time at different values of filtration rates $\mathrm{Fe}=2 \mathrm{mg} / \mathrm{L}, \mathrm{C}_{\mathrm{i}}=14 \mathrm{NTU}$.

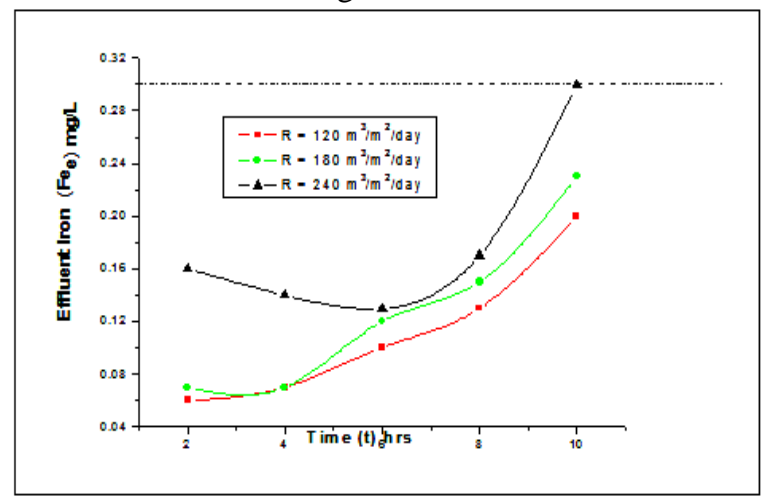

Fig. 9. The effluent iron versus time at different filtration rates $\mathrm{Fe}=3 \mathrm{mg} / \mathrm{L}, \quad \mathrm{C}_{\mathrm{i}}=32 \mathrm{NTU}$.

Table 4.

Removal efficiency of iron for different filtration rates with and without coagulant at $\mathrm{Fe}_{\mathrm{in}}=2 \mathrm{mg} / \mathrm{l}$

\begin{tabular}{|c|c|c|c|}
\hline $\begin{array}{c}\text { Iron Removal } \\
\text { Efficiency For } \mathrm{Fe}_{\text {in }}= \\
2 \mathrm{mg} / \mathrm{l}\end{array}$ & $\mathrm{R}=120\left(\mathrm{~m}^{3} / \mathrm{m}^{2} /\right.$ day $)$ & $\mathrm{R}=180\left(\mathrm{~m}^{3} / \mathrm{m}^{2} /\right.$ day $)$ & $\mathrm{R}=240\left(\mathrm{~m}^{3} / \mathrm{m}^{2} /\right.$ day $)$ \\
\hline Without coagulation & $96.7 \%$ & $95.7 \%$ & $89.8 \%$ \\
\hline With coagulation & $97.1 \%$ & $96.3 \%$ & $78.0 \%$ \\
\hline
\end{tabular}




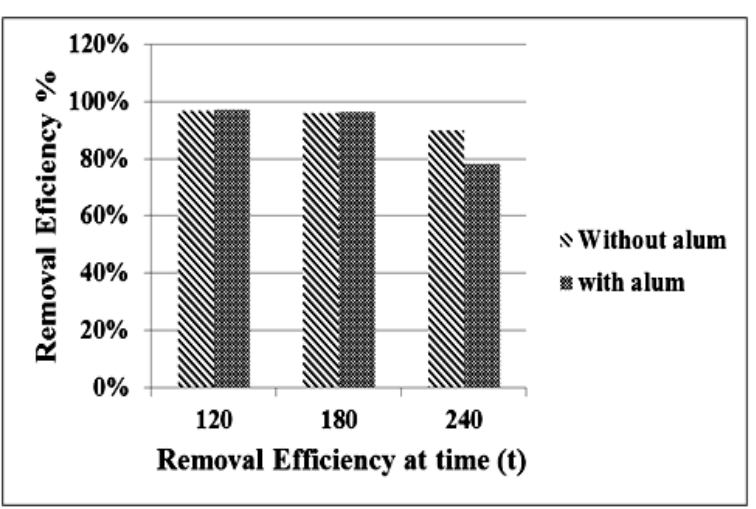

Fig. 10. Iron Removal Efficiency at time (t) and different filtration rates $\left(\mathrm{m}^{3} / \mathrm{m}^{2} /\right.$ day)

\subsection{Removal efficiency of iron and turbidity}

A comparison was mad to investigate the removal efficiency of iron and turbidity for all different filtration rates with and without coagulation.

Table 5.

Removal efficiency of iron for different filtration rates with and without coagulant at $\mathrm{Fe}_{\text {in }}=3 \mathrm{mg} / \mathrm{l}$

\begin{tabular}{|c|c|c|c|}
\hline \multirow{2}{*}{$\begin{array}{c}\text { Iron Removal } \\
\text { Efficiency For } \mathrm{Fe}_{\mathrm{in}}= \\
3 \mathrm{mg} / \mathrm{l}\end{array}$} & & & \\
\hline & $\begin{array}{r}\mathrm{R}=120 \\
\left(\mathrm{~m}^{3} / \mathrm{m}^{2} / \text { day }\right)\end{array}$ & $\begin{array}{r}\mathrm{R}=180 \\
\left(\mathrm{~m}^{3} / \mathrm{m}^{2} / \text { day }\right)\end{array}$ & $\begin{array}{r}\mathrm{R}=240 \\
\left(\mathrm{~m}^{3} / \mathrm{m}^{2} / \text { day }\right)\end{array}$ \\
\hline $\begin{array}{r}\text { Without } \\
\text { coagulation }\end{array}$ & $97.7 \%$ & $96.4 \%$ & $93.9 \%$ \\
\hline With coagulation & $96.7 \%$ & $96.2 \%$ & $95.1 \%$ \\
\hline
\end{tabular}

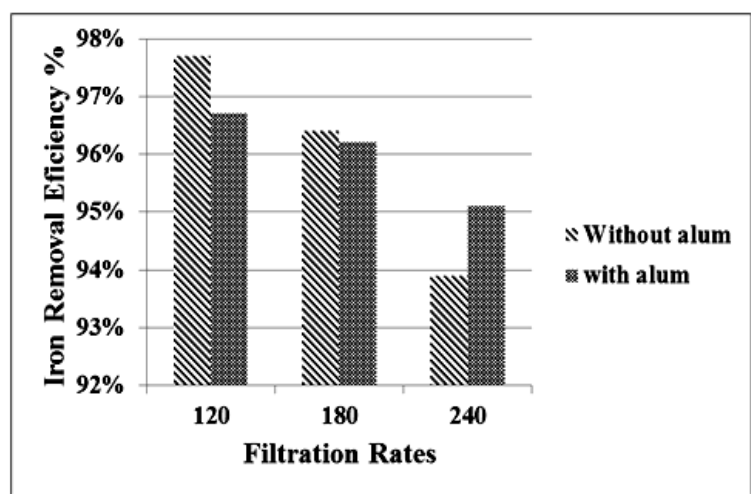

Fig. 11. Removal efficiency with different filtration rates at $\mathrm{Fe}_{\mathrm{in}}=3 \mathrm{mg} / \mathrm{L}$

Table 6.

Removal efficiency of turbidity for different filtration rates with and without coagulant at $\mathrm{Fe}_{\mathrm{in}}=2 \mathrm{mg} / \mathrm{l}$

\begin{tabular}{|c|c|c|c|}
\hline \multirow{2}{*}{$\begin{array}{c}\text { Turbidity Removal Efficiency } \\
\mathrm{Fe}_{\text {in }}=2 \mathrm{mg} / \mathrm{l}\end{array}$} & \multicolumn{3}{|c|}{} \\
\cline { 2 - 4 } & $\mathrm{R}=120\left(\mathrm{~m}^{3} / \mathrm{m}^{2} /\right.$ day $)$ & $\mathrm{R}=180\left(\mathrm{~m}^{3} / \mathrm{m}^{2} /\right.$ day $)$ & $\mathrm{R}=240\left(\mathrm{~m}^{3} / \mathrm{m}^{2} /\right.$ day $)$ \\
\hline Without coagulation & $97.1 \%$ & $95.8 \%$ & $94.2 \%$ \\
\hline With coagulation & $97.2 \%$ & $96.7 \%$ & $94.6 \%$ \\
\hline
\end{tabular}




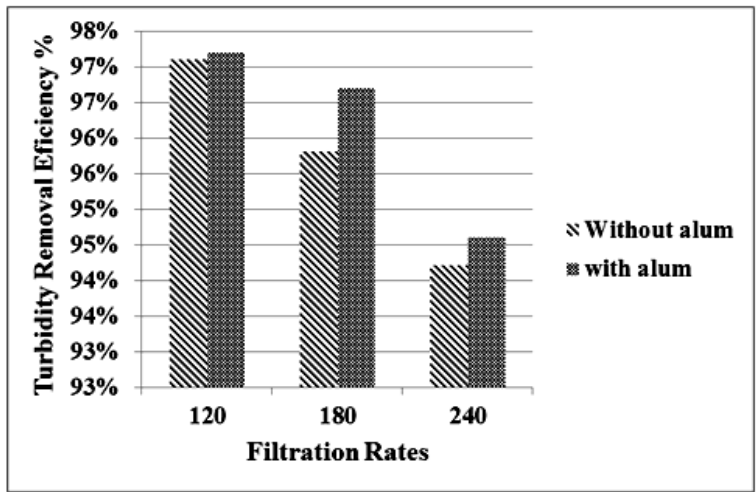

Fig. 12. Turbidity Removal Efficiency at time $(\mathrm{t})$ and different filtration rates $\left(\mathrm{m}^{3} / \mathrm{m}^{2} /\right.$ day $)$

\section{Table 7.}

Removal efficiency of turbidity for different filtration rates with and without coagulant at $\mathrm{Fe}_{\mathrm{in}}=3 \mathrm{mg} / \mathrm{l}$

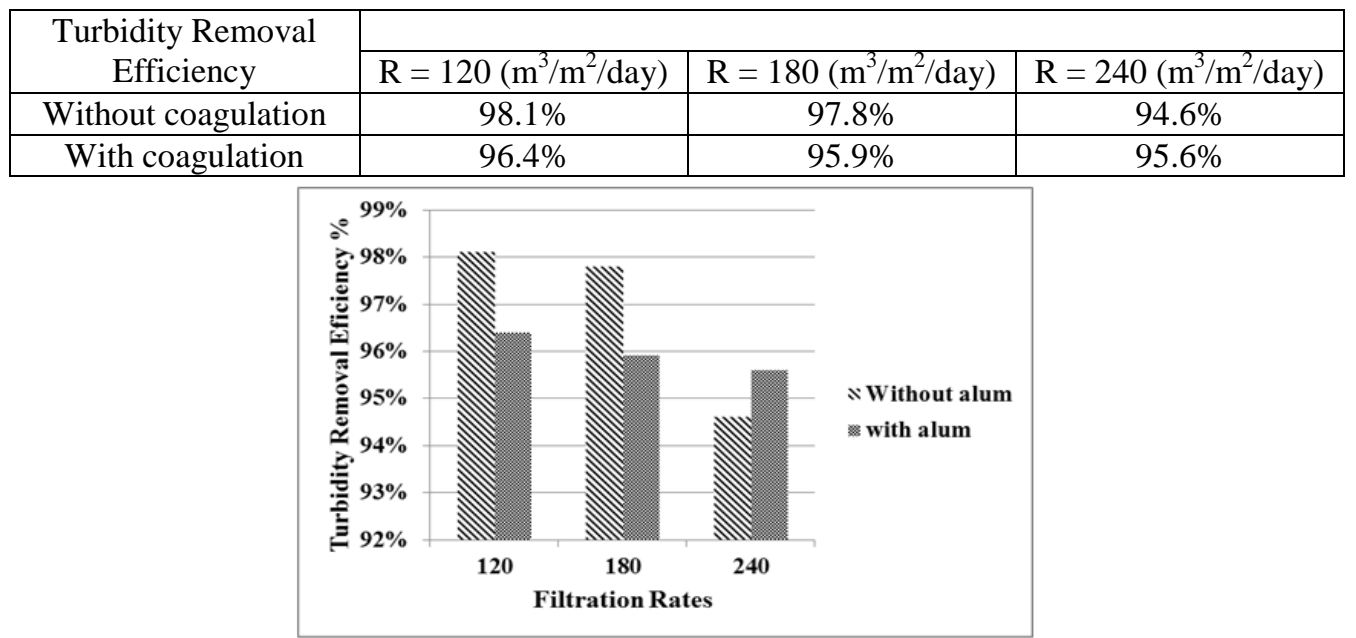

Fig. 13. Turbidity Removal Efficiency at time (t) and different rates $\left(\mathrm{m}^{3} / \mathrm{m}^{2} /\right.$ day)

From Figures (10) through (13), it is clear that the coagulation process at low and high values of influent iron concentration (up to $3 \mathrm{mg} / \mathrm{L}$ ) has no remarkable effect on the removal efficiency for filtration rates upto $210 \mathrm{~m}^{3} / \mathrm{m}^{2} /$ day.

It is obvious to see that removal efficiency decreases as the filtration rates increase. The results are similar to that mentioned in the Egyptian code of practice that no need to coagulation if iron concentration don't exceed $1.5 \mathrm{mg} / \mathrm{L}$. The study also proved that no need to the coagulation process if the iron concentration exceed up to $3 \mathrm{mg} / \mathrm{L}$ and filtration rates are within the allowable limit of $180 \mathrm{~m}^{3} / \mathrm{m}^{2} /$ day.

\section{Conclusions}

Most of Egyptian rural area depends on their water supply on groundwater resources. The main problem in this source of water is the appearance of iron which affects the water portability.

Several solutions had been applied but all of them were highly in cost for both construction and operation specially the electricity and required chemicals. This study 
Heba Mohamed Safwat Abdelazim, Effect of alum coagulation on iron removal in aerated ..........

shows the success of using aeration tank sedimentation and filtration units with and without using chemical addition (using alum as a coagulant).

1. Values of iron concentration in raw water up to $3 \mathrm{mg} / \mathrm{l}$ do not affect the values of iron in effluent water for filtration rates up to $240 \mathrm{~m}^{3} / \mathrm{m}^{2} /$ day.

2. Values of effluent turbidity in filtrate for iron concentration in raw water up to $3 \mathrm{mg} / \mathrm{l}$ not exceed than 1NTU for filtration rates up to $180 \mathrm{~m}^{3} / \mathrm{m}^{2} /$ day.

3. Coagulation and flocculation can be used for influent iron concentration up to $3 \mathrm{mg} / \mathrm{l}$ and filtration rates up to $240 \mathrm{~m}^{3} / \mathrm{m}^{2} /$ day.

This study show the success of using aerated water followed by sedimentation tank and sand filter to the remove iron from raw water with low and high iron concentration.

\section{REFERENCES}

[1] Cheng J., R. Liu, Y. Li and L. Chen " MF for treatment of iron contaminated underground water and fouling countermeasures" in Bioinformatics and Biomedical Engineering, (iCBBE) $20115^{\text {th }}$ International Conference on 2011 Page(s): 1-4.

[2] O'Connor, J.T. (1971) Iron and Manganese. In: Water Quality and Treatment - A Handbook of Public Water Supplies. Chapter 11, p 378-396; McGraw Hill Book Company, New York.

[3] Kothari, N. (1988) Groundwater, iron and manganese: An unwelcome trio. Water/Engineering and Management, Febmary, 25-26.

[4] Montgomery, J.M. Consulting Engineers (1985) Water Treatment, Principles and Design. John Wiley and Sons Inc., USA.

[5] WHO (1996) Guidelines for drinking water quality: 2nd edition, Vol 2 - Health Criteria and other supporting information. WHO, Geneva.

[6] Bean, E.L. (1962) Progress report on water quality criteria. Journal AWWA, 54 (11), 1313-1331.

[7] Aral, N. "Aeration and slow sand filtration in small systems" in Journal of Environmental Science and Health - Part A Environmental Science and Engineering. 1993. Volume 28, Issue 6, Pages 1249-1260.

[8] Robinson, Jr., and Lloyd, R. "How silica affects iron removal from groundwater" in Water Sewage Works. 1975. Volume 122, Issue 3, Pages 74-77.

[9] Das B, Hazarika PI Saikia GI Kalita H, Goswami DC, Das HB, et al. Removal of iron from groundwater by ash: a systematic study of a traditional method. J Hazard Mater. 2007; 141(3):834-41.

[10] Fadel, A. and Fadel, H.A. "Slow sand filtration: A simple technology for iron and manganese removal" in American Water Works Association Annual Conference and Exposition 2010.

[11] Piispanen, J. K., and Sallanko, J. T. "Mn(II) removal from groundwater with manganese oxidecoated filter media" in Journal of Environmental Science and Health - Part A Toxic/Hazardous Substances and Environmental Engineering. 2010. Volume 45, Issue 13, Pages 1732-1740.

[12] Heng, Y. Yanling, G. Weijia, L. Xing, L. Guibai, Effect of pretreatment by permanganate/chlorine on algae fouling control for ultrafiltration (UF) membrane system, Desalination 222 (2008) 74-80

[13] Wen-Hsiang, C., Yung-Hsu, H., Chih-Chao, W. , Meng-Wei, W. M. F. Cybelle and K. Chi-Chuan, "The on-site feasibility study of iron and manganese removal from groundwater by hollowfiber microfiltration" in Journal of Water Supply: Research and Technology-AQUA. 2011. Vol 60 No 6 pp 391-401.

[14] Tang Y., He J., Ma X., You K., Zhang R., Wu W., Fu J., and Zhao, "Simultaneous biological removal of iron, manganese and ammonium nitrogen in simulated groundwater using biological aerated filter" in $4^{\text {th }}$ International Conference on Bioinformatics and Biomedical Engineering, iCBBE 2010, Chengdu.

[15] Olańczuk-Neyman, K. and Bray, R. "The role of physico-chemical and biological processes in manganese and ammonia nitrogen removal from groundwater" in Polish Journal of Environmental Studies. 2000. Volume 9, Issue 2, Pages 91-96.

[16] Postawa, A., Hayes, C., Best Practice Guide on the Control of Iron and Manganese in Water Supply (2013). 


\section{دراسة بعض المتغيرات الطبيعية في المرشحات المئدة الرملية السريعة لإزالة الحديد من المياه الجوفية المهواه}

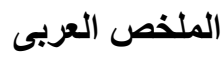

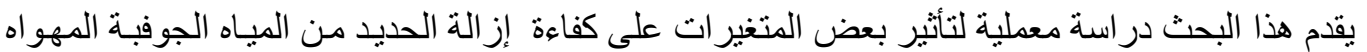

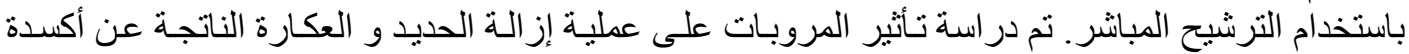

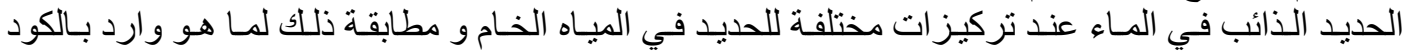

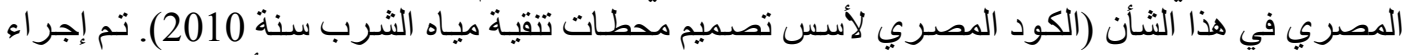

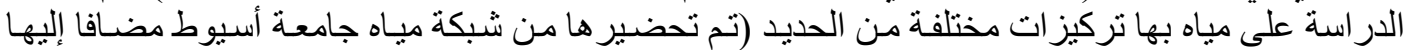

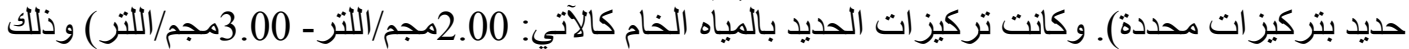

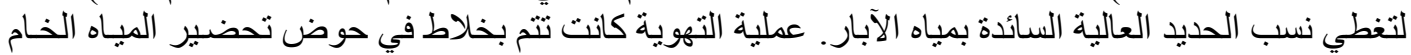

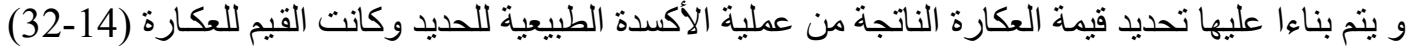

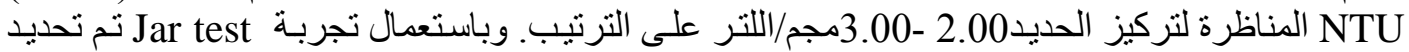

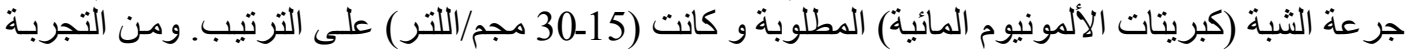

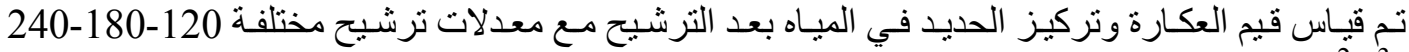

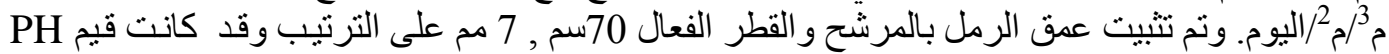

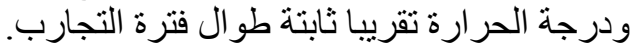

ومن النتائج التي أمكن التوصل إليها تحت الظروف السـابقة هي إمكانيـة استعمال الترشيح المباثـر للميـاه

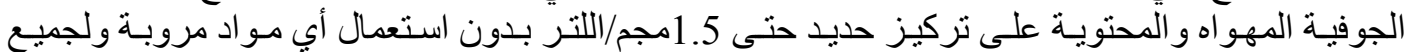

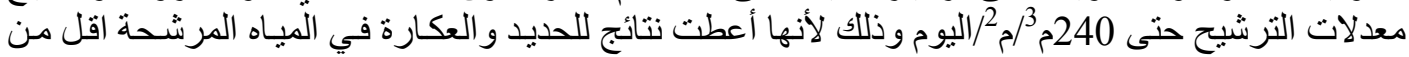

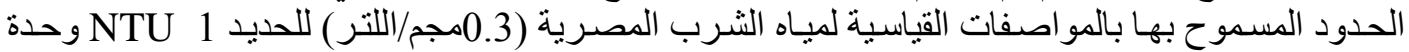

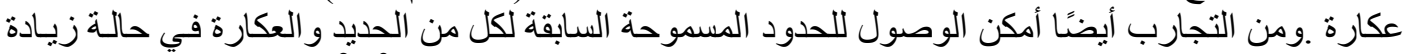

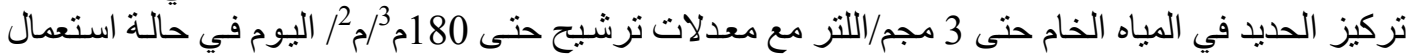

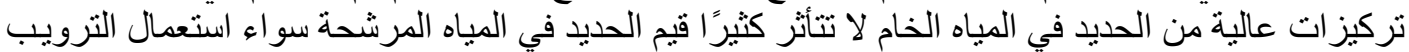

